\title{
Soil-cement blocks: a sustainable alternative for the reuse of industrial solid waste
}

Blocos de solo-cimento: uma alternativa sustentável para o reaproveitamento de resíduos sólidos industriais

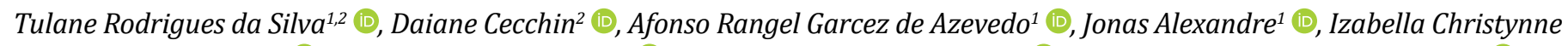
Ribeiro Pinto Valadão ${ }^{2}$ (D), Nivam Alves Bernardino ${ }^{2}$ (D), Dirlane de Fátima do Carmo ${ }^{2}$ (D), Patrícia Ferreira Ponciano Ferraz ${ }^{3}$ (D)

\begin{abstract}
A B S T RAC T
This study aimed to analyze potential industrial solid waste that can be added to soil-cement blocks. A narrative literature review was conducted in the Scopus academic database, using as the search criteria keywords related to the topic, such as soil-cement, building materials, soil-cement blocks, soil-cement bricks, physical and mechanical properties, solid waste, life cycle analysis, and civil construction. A variety of industrial solid waste that can be incorporated into soil-cement blocks was observed, such as waste rock, sludge from water treatment plants, wood sawdust, polyethylene terephthalate fibers (PET), vegetable fibers from loofah, hemp fibers, rice husks, brachiaria grass, poultry eggshells, sugar cane bagasse, wheat and barley straw, welding slag, foundry sand, waste from quartzite mining, construction, and demolition, mechanical turning, pulp industry grains, and steel mill co-products. Among the investigated wastes, those that improved the physical and mechanical properties of the soil-cement blocks were grains from the cellulose industry, rice husks, Brachiaria grass, steel by-products with granulated soil-cement blocks and blast furnace slag. The waste that produced no satisfactory results was sludge from a water treatment plant, sugarcane bagasse, and vegetable loofah. Through this research, it was possible to verify that the behavior of soil-cement blocks is influenced by several factors in their manufacture, mainly regarding the type and percentage of incorporated waste. However, it is important to be concerned with its application in waste blocks so as not to increase the environmental impacts in the long term.
\end{abstract}

Keywords: building materials; sustainability; waste management.

\begin{abstract}
RE S U M 0
Objetivou-se, com o presente estudo, analisar potenciais resíduos sólidos industriais que possam ser adicionados a blocos de solo-cimento. Foi realizada uma revisão bibliográfica narrativa por meio da base acadêmica Scopus, utilizando-se como critérios de busca palavras-chave ligadas ao tema, como: solo-cimento, materiais de construção, blocos de solo-cimento, tijolos solocimento, propriedades físicas e mecânicas, resíduos sólidos, análise de ciclo de vida e construção civil. Observou-se a versatilidade de resíduos sólidos industriais que podem ser incorporados em blocos de solo-cimento, como resíduos de rochas ornamentais, lodo de estações de tratamento de água, serragem de madeira, fibras de politereftalato de etileno, fibras vegetais de bucha, fibras de cânhamo, cascas de arroz, capim braquiária, cascas de ovos aviários, bagaço de cana-de-açúcar, palha de trigo e cevada, escória de soldagem, areia de fundição, rejeitos de mineração de quartzito, de construção e demolição, tornearia mecânica, grãos de indústria de celulose e coprodutos siderúrgicos. Entre os resíduos incorporados que contribuíram para a melhoria nas propriedades físicas e mecânicas dos blocos de solo-cimento estiveram: grãos da indústria de celulose, casca de arroz, capim braquiária, subprodutos siderúrgicos com blocos de solo-cimento granulado e escória de alto forno. Os resíduos sem resultados satisfatórios foram lodo de estação de tratamento de água, bagaço de cana-de-açúcar e bucha vegetal. Por meio desta pesquisa foi possível verificar que o comportamento dos blocos de solo-cimento é influenciado por diversos fatores em sua fabricação, principalmente no que diz respeito ao tipo e ao percentual de resíduos incorporados. Entretanto, é importante a preocupação com a sua aplicação de modo a não potencializar os impactos ambientais em longo prazo.
\end{abstract}

Palavras-chave: materiais de construção; sustentabilidade; gestão de resíduos.

\footnotetext{
${ }^{1}$ Universidade Estadual do Norte Fluminense - Campos dos Goytacazes (RJ), Brazil.

${ }^{2}$ Universidade Federal Fluminense - Niterói (RJ), Brazil.

${ }^{3}$ Universidade Federal de Lavras - Lavras (MG), Brazil.

Correspondence address: Tulane Rodrigues da Silva - Universidade Estadual do Norte Fluminense - Avenida Alberto Lamego, 2000 - Parque Califórnia - CEP: 28013-602 - Campos dos Goytacazes (RJ), Brazil. E-mail: tulanerodrigues@gmail.com

Conflicts of interest: the authors declare that there are no conflicts of interest.
}

Funding: none.

Received on: 10/15/2020. Accepted on: 07/21/2021

https://doi.org/10.5327/Z21769478956

This is an open access article distributed under the terms of the Creative Commons license. 


\section{Introduction}

According to Nascimento (2012), the idea of sustainability started in the 1950s and was related to development due to the expanding production and consumption pattern along with the perception of an environmental crisis in the world. For Romeiro (2012), sustainability is a systemic concept, which proposes complexity, because the social, environmental and economic pillars must be completely interconnected. According to the United Nations (2020) in 1972 at the Stockholm Conference, the existing environmental guidelines began to be discussed through a more holistic perception of sustainability. Since then, the topic has been gaining a lot of space in society, with the union of social, economic, and environmental guidelines becoming increasingly important.

Bricks have played a significant role in construction for thousands of years, because of their outstanding properties such as durability, high strength, and low production costs (Campbell and Pryce, 2003; Zhang et al., 2018). Brick was a fundamental building material in the Mesopotamian, Egyptian, and Roman periods (Fernandes et al., 2010). Increasing sustainability is one of the greatest challenges facing the construction industry and, in this regard, alternative building materials are being developed to mitigate environmental impacts and meet sustainable development, production, and consumption standards (Silva et al., 2009; Araújo et al., 2019; Balaguera et al., 2018; Murmu and Patel, 2018). According to Bruna and Vizioli (2006), sustainability promotes joint action in the construction industry - multiple and interdisciplinary - to meet the needs of humans, including the need for housing, and to organize quality environments for society.

With the intensification of environmental problems arising from the action of humans during the industrial revolution and the growth of consumer goods production, the crisis also reached the construction and architecture models. As a result, construction made with dirt was emphasized as a sustainable alternative to mitigate these impacts. In the 1930s, soil stabilization with binders opened new possibilities for building construction, including masonry components such as soil-cement blocks, known as CEB (Compressed Earth Blocks). Soil-cement was then considered an evolution in construction materials, compared with mud and adobe brick. This was justified by the possibility of industrialization of construction at that time, that is, soil-cement blocks emerged as a component of masonry whose manufacturing process allows the application of an effective quality control system, in addition to ensuring that the blocks have uniform dimensions (Neves and Faria, 2011).

Clay brick masonry is one of the oldest and most durable construction techniques used by mankind. Over the years, as the brick industry has evolved, technological advances in processing (with the development of machines such as excavation equipment and tunnel kilns, among others) has significantly stimulated the production capacity of this type of material (Kadir and Mohajerani, 2011; Zhang, 2013; Zhang et al., 2018). However, Al-Fakih et al. (2019) and Venkatarama Reddy and Jagadish (2003) claim that this advance provoked an increase in the depletion of resources, in addition to greater energy consumption, corresponding to around 30\% more energy than that required to produce concrete blocks and blocks of soil-cement, due to the need to use burning for its manufacture, resulting in a greater carbon footprint, even though concrete and soil-cement blocks use cement in their production process.

According to Kadir and Mohajerani (2012), the masonry block is one of the most complete building material components, due to its physical and mechanical properties, in addition to the innovation of incorporating various wastes in its production. According to Zhang et al. (2018), despite the good workability and accessibility, it is known that the production of sintered masonry blocks has always been a very intensive process in terms of energy and resources, in addition to the large quantities of carbon it consumes. According to Buyle et al. (2013), reducing energy consumption is a major focus of civil construction.

The global urbanization process is one of the main factors responsible for the substantial growth in the generation of solid waste. Developing countries favor irregular disposal in landfills and open landfills (Cardoso et al., 2014; Rodseth et al., 2020). As a result, for example, Kadir and Mohajerani (2011) state that recycling wastes by incorporating them into building materials is an alternative to these issues regarding the disposal of solid waste and mitigation of environmental impacts. Kurmus and Mohajerani (2020) found in their studies that the incorporation of $1 \%$ of cigarette butts in sintered clay bricks can save approximately $10.2 \%$ of burning energy in the manufacturing process.

The natural resource scarcity and the generation of solid waste without proper disposal is a worldwide concern, and this enables ecological viability for construction systems, which encourage sustainable development and process optimization (Araújo et al., 2019; Krishna et al., 2020). According to Ashour et al. (2015), the current global concerns arose from extensive environmental problems, together with the accelerated pace of technological advancement in the industry, especially in construction, and, with that, the interest in the development of alternative building materials gained space, especially materials made of earth. According to Zakham et al. (2018), stabilized soil blocks help improve the construction energy efficiency, mainly because they have low thermal conductivity. In this way, it is possible to use them to improve the thermal and acoustic insulation in buildings.

The construction and demolition industry is responsible for $40 \%$ of the energy consumed worldwide and for a third of greenhouse gas emissions (Silva et al., 2010; Muñoz et al., 2016). According to De Lassio et al. (2016), with the growth of the demand for building materials, there was an increase in the consumption of raw materials and energy that stands out mainly during the extraction, processing, and material transport phases. The current global amount of solid waste generation is approximately 2.01 billion tons per year, and it is expected to increase to approximately 3.40 billion tons per year by 2050 (Slipa Kasa et al., 2018). The use of solid industrial waste in construction activities as alternative stabilizers has proven to be a viable solution for reducing 
environmental impact, in addition to the social and economic benefits (Arrigoni et al., 2017; Sekhar and Nayak, 2018).

According to Smol et al (2015) and Murmu and Patel (2018), the growing demand for ecological and sustainable products has encouraged studies of alternative methods and materials to produce building bricks. According to Raut and Gomez (2017), the raw materials consumed by the construction industry represent approximately $24 \%$ of the global raw material supply. Thus, to achieve the goal of sustainable development, the selection of a construction material plays a very significant role. Soil-cement blocks pose a solution to these issues, because they are easily manufactured by a process that does not require burning, decreases the amount of cement used, and still allows the incorporation of waste materials in their composition. In addition, the use of cement blocks reduces costs by up to $40 \%$ compared with traditional masonry, especially in popular housing. In this way, cement blocks can be considered eco-friendly relative to traditional masonry blocks (Bruna and Vizioli, 2006; Sena et al., 2017).

This study aimed to conduct a narrative literature review about different types of industrial solid waste evaluated for the possibility of addition to soil-cement blocks and bricks. Searches were conducted in the Scopus bibliographic database. This database was selected for the relevance of the indexed papers focusing on the area and topic addressed. At the end of the database search, duplicate references were excluded. The searches were made between November 12 and November 30, 2020, using the keywords: soil-cement, building materials, soil-cement blocks, soil-cement bricks, physical and mechanical properties, solid waste, life cycle analysis, and civil construction. The keywords were combined by means of the operators "and", "or", and "not", which were related to the diversity of waste limited to soil-cement blocks and bricks, as well as combined for the association of these materials with their life cycle in the construction industry. In addition, truncation was used to gain more control over search variations. The inclusion criteria were original articles and literature reviews indexed within a 17 -year time frame (articles published between 2003 and 2020), articles written in Portuguese and English, and articles that addressed the main properties evaluated for this type of material, such as physical and mechanical properties, as well as literature that evaluated different types of incorporated waste. The exclusion criteria were articles that addressed other types of materials made with soil-cement, as well as articles that did not report on the addition of waste to construction materials.

For data analysis, a qualitative content analysis protocol was adopted, following the methodology proposed by Bardin (1977), and divided into pre-analysis, analysis, and data interpretation steps. For the pre-analysis, the first stage was a floating analysis, consisting of a survey of bibliographic references to the theme studied; in the second stage, the choice of literature that comprised the body of the analysis was made; and the third stage was the formulation of the choice of information for each content. In the analysis (exploration of the material), the information gathered in the pre-analysis stage was compiled in spreadsheets, and the informational content was categorized. Finally, in the data interpretation stage, this categorization of information was considered so that the discussion was related to the main topics that make up the sections discussed in this paper: Soil-cement; Industrial solid waste in soil-cement blocks; Life Cycle Analysis (LCA) in construction: An alternative to evaluate soil-cement blocks with industrial solid waste.

\section{Soil-cement}

Soil-cement is the product resulting from the mixture of soil, cement, and water compacted at the optimum humidity to provide maximum density. To verify the suitability of a soil for stabilization with cement, it is necessary to perform granulometric analysis and determine consistency limits (Ferreira et al., 2018). Once the soil is chosen, soil and soil-cement compaction tests must be carried out to quantify compaction control values. The molding process of the soil-cement brick consists of compaction by means of a manual or hydraulic press, which reduces its porosity through a compressive force and preserves the dimensional symmetry of the interlocking bricks' faces (ABCP, 2000; Ferreira et al., 2018). The addition of cement to the soil increases the optimum humidity value of the mixture compared with that of natural soil (Ferreira et al., 2018).

Soil-cement blocks with a cement content greater than $10 \%$ may not be considered advantageous in terms of cost, but a cement content of less than 5\% may affect the technological properties of the material. Soils with a plasticity index (PI) between 15 and 25 are the most suitable for soil-cement blocks, because a greater plasticity or clay could cause a bigger interference in the connection between cement and fine aggregates and, consequently, in water absorption due to the occurrence of retractions in the drying process and an increase in the appearance of cracks.

The main properties analyzed in this type of block are compressive strength and water absorption according to Brazilian Technical Standards ABNT NBR 8491 and ABNT NBR 8492. For compressive strength, the blocks must reach a minimum value of $2.0 \mathrm{MPa}$ (average), and for water absorption, less than or equal to 20\% (average) (ABNT, 2012a, 2012b; Ferreira et al., 2018; Murmu and Patel, 2018). The amount of water has a dominant effect on the mechanical performance of clay bricks and sintered masonry. Each component of the block, including pores of water and air, plays a role and interacts with others in the mix, contributing to the overall strength of the system (Li Piani et al., 2020). The proportion of water in the mixture is between 5 and $20 \%$, and the optimum humidity is defined as the value of humidity corresponding to the value of the maximum dry density, that is, the ideal amount of water required to obtain stable compaction (Campos et al., 2019). 
According to Al-Jabri et al. (2017), soils with a higher clay content are more compressible than those with a lower one. The increase in clay content, cement, and density in the soil-cement block directly influences the increase in the thermal conductivity of the material (Balaji et al., 2017; Saidi et al., 2018). According to McGregor et al. (2014) and Rempel and Rempel (2016), unburned masonry has a high potential to regulate its internal humidity, and hygroscopic earth buildings are characterized by the maintenance of comfortable internal temperatures.

Soil-cement blocks are a more sustainable alternative to traditional masonryblocks. Despite the use of cement, the process of manufacturing soil-cement blocks does not involve burning, which minimizes greenhouse gas emissions (Paschoalin Filho et al., 2016; Azevedo et al., 2019). Segantini and Wada (2011) and Azevedo et al. (2019) emphasize that this constructive method streamlines the construction process, reduces the amount of waste generated, and reduces the consumption of mortar. This type of block is superimposed on the settlement, forming ducts through which hydraulic wires and pipes can be passed, besides offering thermal and acoustic comfort (Weber et al., 2017), as can be seen in Figure 1.

\section{Industrial solid waste in soil-cement blocks}

According to Huarachi et al. (2020), it is necessary to quantify the real impact of alternative blocks through different waste addition scenarios. Zhang (2013) adds that it is important to ensure adequate treatment for the waste that contains contaminants to produce materials. Literature (Table 1) shows the versatility of industrial solid waste incorporated in the production of soil-cement blocks.
According to Anjum et al. (2017), the addition of sludge from wastewater treatment plants directly affects the increase in water absorption in the block, as it is a plastic solid waste. Because of that, it also affects the cement hydration reactions next to the organic matter present in the sludge and the type of soil used, since the sludge traps large amounts of water; therefore, it lacks an adequate amount of water to complete these reactions.

Rodrigues and Holanda (2015) also analyzed the addition of waste from a water treatment plant to soil-cement blocks and observed that the amount of soil used was replaced by up to $1.25 \%$ of this waste, although the main limitation was associated with the increase in water absorption due to waste plasticity. Having an adequate amount of water helps in the homogenization, hydration, and crystallization process of the cement, that is, it provides fluidity, plasticity, and workability to the material. In addition, the water/cement factor must always be as low as possible, within the required characteristics of the block and the quality of the materials available for its composition. The higher the water content in the mixture, the greater the tendency for exudation to occur, which causes the water to reach the surface of the block, creating a greater number of voids inside and, consequently, reducing the resistance, increasing the permeability, and impairing the block's durability (Castro and Pandolfelli, 2009).

According to Barros et al. (2020), soil-cement blocks with the use of ornamental stone wastes and polyester resin using methyl ethyl ketone peroxide as a catalyst showed superior results for compressive strength. The result for water absorption was lower than that of conventional
(A)

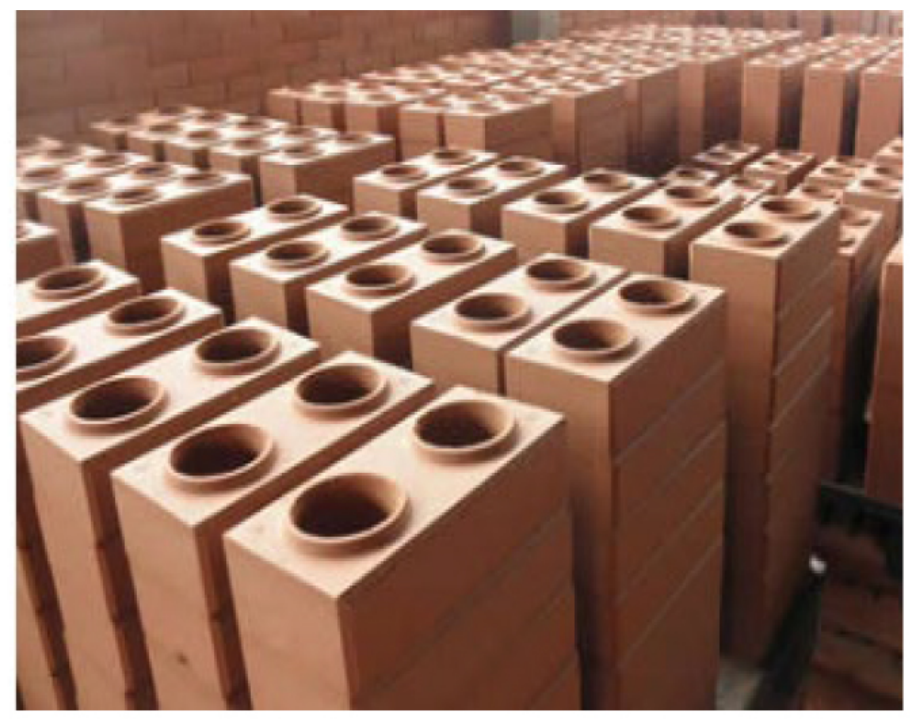

(B)

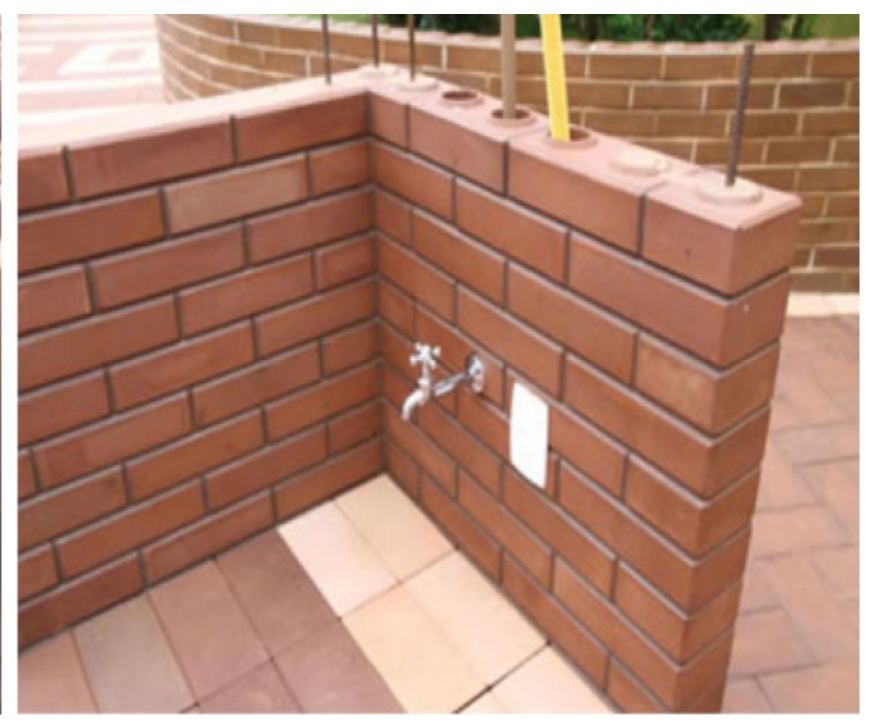

Figure 1 - Soil-cement blocks. (A) Holes in soil-cement blocks. (B) Ducts in soil-cement blocks. Source: Eco Máquinas. 
Table 1 - Studies on the incorporation of different industrial solid wastes in soil-cement blocks.

Title

Ecological bricks from dimension stone waste and polyester resin

Assessment of Mechanical Properties and the Influence of the Addition of Sawdust in Soil-Cement Bricks Using the Technique of Ultrasonic Anisotropic Inspection

Evaluation of compressive strength and water absorption of soilcement bricks manufactured with addition of pet wastes

Brick solo cement with vegetable fiber addition: an alternative in civil construction

Quality evaluation of soil-cement-plant waste bricks by the combination of destructive and non-destructive tests

Manufacture of soil-cement bricks with the addition of sugarcane bagasse ash

Characterization of soil-cement bricks with incorporation of used foundry sand

Incorporation of solid residues from mechanical turning in soilcement bricks manufacturing

Recycling of Water Treatment Plant Waste for Production of SoilCement Bricks

Physical-mechanical properties of soil-cement bricks with the addition of the fine fraction from the quartzite mining tailings (State of Minas Gerais - Brazil)

Effect of incorporation of grits waste on the densification behavior of soil cement bricks

Influence of industrial solid waste addition on properties of soilcement bricks

Thermal conductivity of unfired earth bricks reinforced by agricultural wastes with cement and gypsum

Sorption characteristics of stabilised soil blocks embedded with waste plastic fibres

Evaluation of physical and mechanical properties of soil-cement bricks formulated with steel co-products

Utilization of granulated blast furnace slag and cement in the manufacture of compressed stabilized earth blocks

Thermal performance of fired and unfired earth bricks walls

Sustainable unfired bricks manufacturing from construction and demolition wastes

Ecological brick made with non-cash banknotes
Matéria

\section{Journal}

Earth Science Malaysia

Construction and

Building Materials

Journal of materials in civil engineering

Acta Scientiarum

Research, Society and Development

Revista Brasileira de Engenharia Agrícola e Ambiental

Engenharia Agrícola

Cerâmica

Nativa

Procedia Materials Science

Bulletin of Engineering Geology and the Environment

\section{Cerâmica}

Cerâmica

Energy and Buildings

Construction and

Building Materials

Construction and Building Materials

Journal of Building Engineering

Construction and Building Materials

Semioses Inovação, desenvolvimento $e$ sustentabilidade

\section{Authors}

Anjum et al. (2017)

Barros et al. (2020)

Carrasco et al. (2014)

Paschoalin Filho et al. (2016)

Cristina et al. (2018)

Loofah vegetable fiber ( $L$ uffa Cylindrica)

Ferreira and Cunha (2017)

Rice husk and Brachiaria grass (Brachiaria brizantha $\mathrm{c} v$. Marandu)

Jordan et al. (2019)

Sugar cane bagasse

Leonel et al. (2017)

Discarded foundry sand

Oliveira et al. (2014)

Mechanical turning

Rodrigues and

Holanda (2015)

Sludge from a water treatment plant

Reis et al. (2020)

Quartzite mining waste

Siqueira and Holanda (2015)

Siqueira et al. (2016)

Poultry eggshells and welding slag

Ashour et al. (2015)

Wheat and barley straw

Subramaniaprasad et al. (2014)

Plastic fibers (PET bottles and bags)

Steel co-products: Balloon blast furnace dust powder, dedusting powder, electric arc furnace slag, and defective granulated soilcement blocks

Sekhar and Nayak (2018)

Granulated blast furnace slag

Bruno et al. (2020)

Hemp fibers

Seco et al. (2018)

Construction and demolition waste (concrete and ceramics)

Valadão et al. (2017)

Worthless cash bills 
sintered block. The soil-cement blocks analyzed showed good thermal stability and fire strength using $90 \%$ of limestone wastes.

Carrasco et al. (2014) observed in soil-cement blocks with the addition of wood sawdust and with different block shapes that the mechanical characteristics of soil-cement blocks depend not only on the type of soil used, but also on the form and configuration of blocks and prisms. The authors also pointed out that the incorporation of wood sawdust into sandy soil increased its compressive capacity, strength, modulus of elasticity, and ductility. In clayey soils, it caused a decrease in compressive strength, but an increase in elasticity and ductility modulus. The authors also demonstrated the results obtained through non-destructive tests by ultrasonic waves that allowed estimation of the values of compressive strength and elasticity modulus of samples, blocks, and prisms, relating the variation of soil, cement, and wastes, in addition to allowing the analysis of the structural characteristics of the aggregate.

Paschoalin Filho et al. (2016) demonstrated positive results regarding the reduction of (polyethylene terephthalate) PET waste for the environment with the manufacture of soil-cement blocks. The authors evaluated blocks with waste added at proportions of 20,15 and $10 \%$, and cement at proportions of 15,20 , and $25 \%$, and found that, with the addition of $10 \%$ PET, it was possible to reuse approximately $300 \mathrm{~g}$ of PET in each block. Although the results showed low values of compressive strength, they still proved to be an alternative solution for masonry works that are not subjected to heavy loads or structural functions.

Cristina et al. (2018) showed that soil-cement blocks with added loofah vegetable fiber presented low compressive strength under conditions of $5 \%$ and $10 \%$ fiber variation and molded with a water content of $17.5 \%$ and a cement content of $5 \%$. The authors found that, with the increase in waste, there was low adherence of the vegetable fiber to the cement with the amount of water used.

Bruno et al. (2020) demonstrated the incorporation of $1.5 \%$ of the hemp fibers mass in soil-cement blocks with a water content of 5.4\% to facilitate mixing and hypercompaction of the material. The authors found that the insulating fibers provided better thermal performance due to their low density, low porosity, and low thermal conductivity.

Ferreira et al. (2008) evaluated soil-cement blocks with the addition of rice husks and Brachiaria grass with different proportions of cement $(60,70,80$, and $90 \%)$ and waste $(10,20,30$, and $40 \%)$. The authors stated that the best results, in terms of compressive strength and water absorption, were obtained by incorporating the wastes as $10 \%$ of the cement content. Ferreira and Cunha (2017) also used the addition of rice husks and Brachiaria in their studies of soil-cement blocks and pointed out that, to achieve the maximum apparent specific weight of the molding blocks, the optimum moisture values of the soil at the compaction tests should be used. The authors performed an anisotropic strength measurement, a non-destructive test using ul- trasonic waves, to characterize the technical quality of the blocks in physical-mechanical, and elastic-acoustic terms.

Sekhar and Nayak (2018) evaluated compressed blocks with the addition of granulated blast furnace slag (BFS) and observed that it was possible to substitute 25 and 20\%, respectively, for two types of soil used (lithogenic and lateritic), an improvement of 53 and $40 \%$, respectively, in the compressive strength. The authors calculated the levels of addition of each component mixture and observed that the cement content, in $10 \%$ in the mass mixture, directly interfered in the compression force with the lithogenic soil, with an improvement of up to $390 \%$. With the lateritic soil, a cement content of $6 \%$ showed that there was an improvement of $209 \%$.

Jordan et al. (2019) studied soil-cement blocks with and without the addition of sugarcane bagasse and observed that the lack of pre-treatment of the waste interfered with the physical and mechanical results of the block due to the presence of impurities and granulometric variables, which contributed to a decrease in the quality of the mixtures.

Leonel et al. (2017), when evaluating a mixture composed of $10 \%$ cement, $0-25 \%$ commercial sand, $0-65 \%$ foundry sand, $25-65 \%$ clay, and $15-30 \%$ gravel powder, observed a reduction in water absorption with the addition of discarded foundry sand combined with crushed stone, although the mechanical strength remained stable.

Oliveira et al. (2014) evaluated soil-cement blocks with the addition of mechanical turning waste with 0,10 , and $15 \%$ waste variation, and $10 \%$ cement content in the mixture. The results showed improvement in the mechanical properties with $15 \%$ addition of waste in relation to the block without waste; however, they did not reach the values established by the norm.

Seco et al. (2018) evaluated the incorporation of construction and demolition waste. The authors obtained different percentage results for maximum addition of each residue due to the workability of each mixture, with $50 \%$ of maximum addition for concrete and $30 \%$ for ceramic residue.

Reis et al. (2020) analyzed the physical-mechanical aspects of soil-cement blocks with the addition of tailings from quartzite mining and found that the incorporation of the waste reduced the limits of liquidity and plasticity due to the decrease in the percentage of the clay fraction of the soil, since clays, unlike sands, have a plastic behavior and high agglutination capacity.

Siqueira and Holanda (2015) manufactured soil-cement blocks with the addition of grains from the cellulose industry and analyzed the incorporation of up to $20 \%$ by weight of cement in the manufacture of soil-cement blocks with a water content of $16 \%$ in relation to the total block weight. The authors varied the waste by 10,20 , and $30 \%$, and observed that the compressive strength increased by $15 \%$ in relation to the reference line, without adding any waste. For additions of waste above $20 \%$, the grain filling effect was lower, and water absorption increased. As for durability, for additions of up to $20 \%$ of grains, the loss of mass of the blocks decreased, and for additions greater than $20 \%$ of grains, it increased. 
Siqueira et al. (2016) evaluated the addition of poultry eggshell and welding slag wastes for the manufacture of soil-cement blocks and found that up to $15 \%$ welding slag waste could be incorporated into the block as a substitute for soil and that the wastes of poultry eggshells could replace up to $30 \%$ in the cement composition.

Subramaniaprasad et al. (2014) analyzed the incorporation of plastic fibers in compressed blocks and observed that the plastic fiber forms interconnected channels and helps to increase water absorption when the samples are completely submerged in water. When the blocks with added fiber underwent greater molding pressure, water absorption decreased due to greater soil compaction and the considerable reduction of empty spaces between the waste and the high-pressure soil. Subramaniaprasad et al. (2015) used evaluation parameters with a variation of $7.5,10$, and $15 \%$ of cement, types of fiber (water bottles and transportation bags), fiber length $(1$ and $2 \mathrm{~cm}$ ) and fiber percentage $(0.1$ and $0.2 \%)$. With that, the authors were able to find a 4.5 -fold increase in the block's tensile strength.

Ben Mansour et al. (2017) showed in their study on acoustics that pressed blocks with a high apparent density are characterized by high airflow resistivity due to their low porosity and high sinuosity. When there is a decrease in the compaction pressure, there is an increase in porosity and a reduction in the airflow resistivity of the material; therefore, it is more efficient in relation to sound absorption at a low density, i.e., it is a better sound absorber, than at a higher density.

Ashour et al. (2015) studied the incorporation of wheat and barley straw into soil-cement blocks. The authors observed the density and thermal conductivity of the blocks with a variation in the percentage of wheat straw and barley from 0 to $3 \%$. They concluded that there was a decrease in the thermal conductivity of the blocks by up to $54.4 \%$ (wheat) and 53\% (barley straw), respectively, in relation to the blocks without residue. As for the density of the blocks, there was a decrease of about 9.8 to $22 \%$ in relation to the blocks without residue incorporation.

According to Castro et al. (2016), it is possible to incorporate steel by-products, such as balloon blast furnace dust powder, electric furnace dust, and granulated blast furnace slag. The authors point out that the wastes used are composed of granulometries corresponding to the typical range of fine and medium sand, except for balloon blast furnace dust powder, which is finer. Another aspect they mention is alteration of the cement mix as an alternative to increase granule cohesion and reach higher strength values, together with the adequate dosage of added wastes.

Valadão et al. (2017) analyzed the incorporation of worthless cash banknotes into soil-cement blocks in proportions of 10,15, 20, and $25 \%$ of the waste and observed an increase in the compressive strength with the addition of the waste, considering that waste pre-treatment provided greater compaction of the block.

A study by Sekhar and Nayak (2018) evaluated compressed blocks with granulated blast furnace slag added to different types of soil (lithomargic soil and lateritic soil) and waste added in different proportions.
The authors observed that a cement content of $10 \%$ in the mass mixture directly interfered in the compression force with the lithogenic soil, with an improvement of up to $390 \%$. With the lateritic soil, a $6 \%$ cement content showed an improvement of 209\%. Siqueira and Holan$\mathrm{da}$ (2015) manufactured soil-cement blocks by adding grains from the cellulose industry. The authors observed that the compressive strength increased by $15 \%$ in relation to the reference line, without adding waste.

Subramaniaprasad et al. (2015) analyzed the incorporation of plastic fibers in pressed blocks and found a 4.5 -fold increase in the block's tensile strength. Ashour et al. (2015) studied the relationship between the incorporation of wheat straw and barley into soil-cement blocks and found a reduction in the thermal conductivity of the block by up to $54.4 \%$, compared with the block without straws. With the increase in barley straw, the thermal conductivity decreased by up to $53 \%$ in relation to the block without waste, and the density decreased about $9.8 \%$, to $22 \%$.

According to the related literature in this study, the behavior of soil-cement blocks is influenced by several factors, including the type of soil used, the cement content, the percentage of incorporation and replacement of residue, and the type of waste incorporated (shown in Table 1). In addition, the tests of physical-chemical properties must be in accordance with the current standards for validating the material performance, including quality and accuracy in the manufacturing steps, mainly regarding the mixture homogenization, moisture content and compaction energy of the material (Murmu and Patel, 2018).

In general, there are difficulties in quantifying a complete comparison of the data present in the different authors listed in this review. In this context, a comparative synthesis was established for some of the advances obtained by each study (Tables 2 and 3):

There is a concern that the incorporation of wastes implies changes in the physical and mechanical properties of soil-cement bricks, impairing their performance. It is also necessary to pay attention to possible contamination problems that this incorporated waste may inflict on the environment with the effects of waste over time. Santos et al. (2013) studied the addition of leather waste to soil-cement bricks in different proportions $(10,15,20$, and $30 \%)$ and observed that only the sample relative to the addition of $10 \%$ showed results for chromium below the maximum limit allowed per liter of leachate, thus being considered non-hazardous by NBR 10004 (ABNT, 2004a). In contrast, other percentages of addition analyzed presented chromium content above the limit set by the standard, thus being considered hazardous (ABNT, 2004a). Despite the study showing satisfactory results in relation to water strength and absorption, the impossibility of retaining chromium in bricks has become a limiting factor in its use and must be considered.

A study by Pinheiro et al. (2013) evaluated the effects of incorporating grits waste into soil-cement bricks. The authors found that the soil-cement brick with grits added was characterized as non-hazardous by NBR 10004 (ABNT, 2004a), which can be used without restriction. 
Table 2 - Summary of the bibliographic review regarding the factors that influence the behavior of the soil-cement block with the incorporation of industrial solid waste.

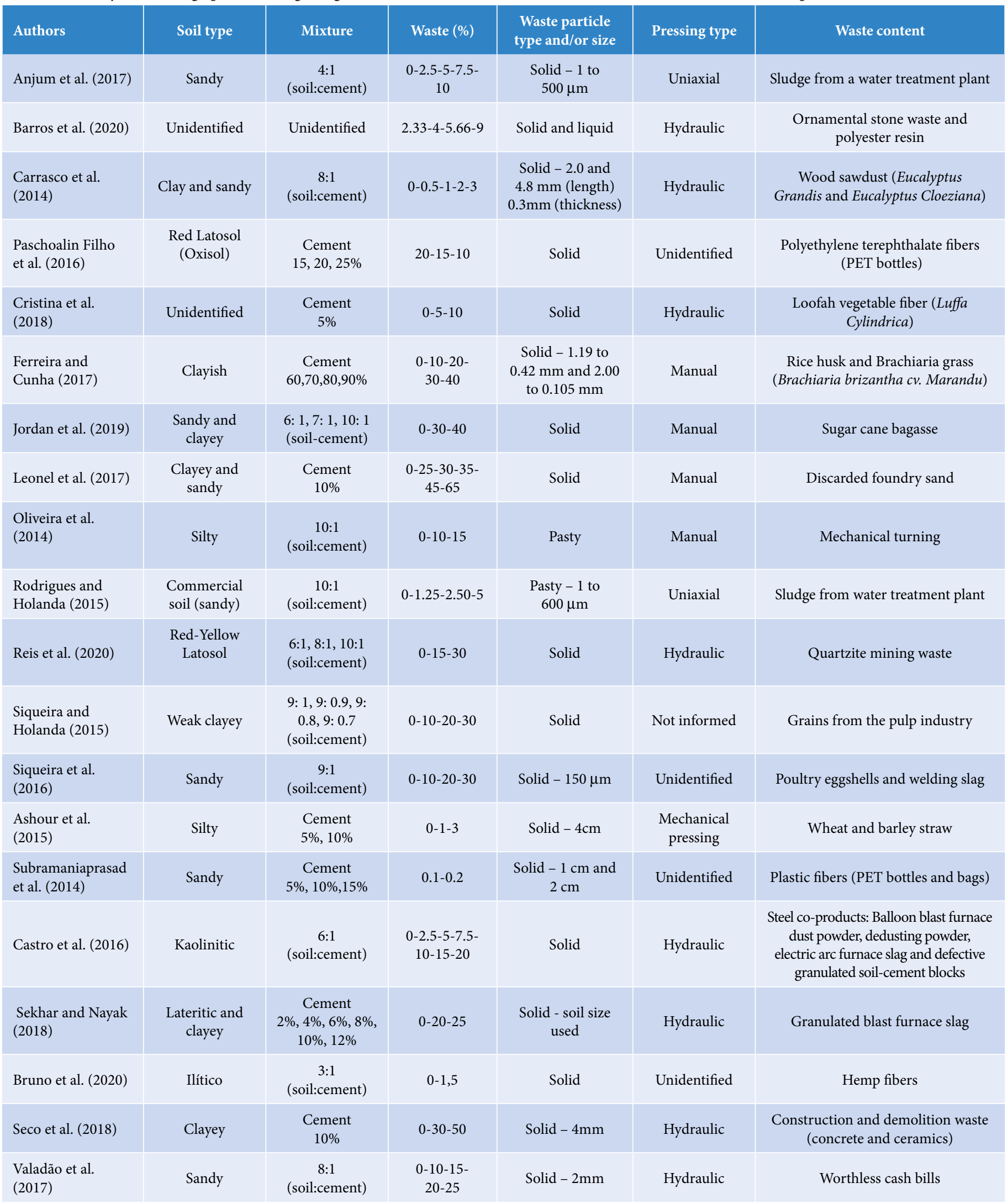


Table 3 - Synthesis of the main tests and results of the literature review on soil-cement blocks with industrial solid waste.

\begin{tabular}{|c|c|c|c|}
\hline Authors & Tests with the waste & Tests with the blocks & Main results \\
\hline Anjum et al. (2017) & Chemical analysis by X-ray spectrometry & $\begin{array}{l}\text { Simple compressive strength, water } \\
\text { absorption, and bulk density }\end{array}$ & $\begin{array}{l}\text { Reduced density and compressive } \\
\text { strength and increased water absorption }\end{array}$ \\
\hline Barros et al. (2020) & $\begin{array}{l}\text { Fourier Transform-Infrared } \\
\text { Spectroscopy (FTIR) } \\
\text { thermogravimetry (TG), X-ray diffraction } \\
\text { (XRD), X-ray fluorescence spectrometry } \\
\text { (XRF), Scanning electron microscopy } \\
\text { (SEM) }\end{array}$ & $\begin{array}{c}\text { Compressive strength, water absorption, } \\
\text { TG/DTG, and } \\
\text { flammability }\end{array}$ & $\begin{array}{l}\text { Increase in compressive strength and fire } \\
\text { strength and decreased water absorption }\end{array}$ \\
\hline Carrasco et al. (2014) & Particle Size Distribution (PSD) & $\begin{array}{l}\text { Proctor compaction, prism test, } \\
\text { ultrasonic compressive strength, tensile } \\
\text { strength }\end{array}$ & $\begin{array}{l}\text { Reduced compressive and tensile } \\
\text { strengths, increased ductility for clayey } \\
\text { soil and increased compressive and tensile } \\
\text { strengths and ductility for sandy soil }\end{array}$ \\
\hline $\begin{array}{l}\text { Paschoalin Filho et al. } \\
\text { (2016) }\end{array}$ & Particle Size Distribution (PSD) & $\begin{array}{l}\text { Particle size distribution, compaction test, } \\
\text { simple compressive strength and water } \\
\text { absorption }\end{array}$ & $\begin{array}{l}\text { Reduced compressive strength and water } \\
\text { absorption }\end{array}$ \\
\hline Cristina et al. (2018) & Unidentified & $\begin{array}{l}\text { Particle size distribution, simple } \\
\text { compressive strength and water } \\
\text { absorption }\end{array}$ & $\begin{array}{l}\text { Reduced compressive strength, high } \\
\text { porosity and high water absorption }\end{array}$ \\
\hline $\begin{array}{l}\text { Ferreira and Cunha } \\
(2017)\end{array}$ & $\begin{array}{l}\text { Particle size distribution and apparent } \\
\text { density, pre-treatment in a hydrated lime } \\
\text { solution and drying }\end{array}$ & $\begin{array}{l}\text { Proctor compaction, prism test, } \\
\text { ultrasonic compressive strength, tensile } \\
\text { strength }\end{array}$ & $\begin{array}{l}\text { Increase in compressive strength (rice } \\
\text { husk), reduction in specific weight and } \\
\text { anisotropic strength (Branchiaria grass) }\end{array}$ \\
\hline Jordan et al. (2019) & Drying and screening & $\begin{array}{l}\text { Particle size distribution, simple } \\
\text { compressive strength and water } \\
\text { absorption }\end{array}$ & $\begin{array}{l}\text { Low compressive strength, increased } \\
\text { porosity and water absorption }\end{array}$ \\
\hline Leonel et al. (2017) & $\begin{array}{l}\text { X-ray diffraction }(\mathrm{XRD}) \mathrm{X} \text {-ray } \\
\text { fluorescence }(\mathrm{XRF})\end{array}$ & $\begin{array}{l}\text { Isothermal colorimetric test, compressive } \\
\text { strength, tensile strength, durability and } \\
\text { water absorption }\end{array}$ & $\begin{array}{l}\text { The replacement of the block sand } \\
\text { by waste caused a reduction in the } \\
\text { compressive strength }\end{array}$ \\
\hline Oliveira et al. (2014) & Drying and screening & $\begin{array}{l}\text { Particle size distribution, simple } \\
\text { compressive strength, prism test, and } \\
\text { water absorption }\end{array}$ & $\begin{array}{l}\text { Increase in compressive strength and low } \\
\text { water absorption with increased waste }\end{array}$ \\
\hline $\begin{array}{l}\text { Rodrigues and } \\
\text { Holanda (2015) }\end{array}$ & $\begin{array}{l}\text { Sedimentation, drying and screening, } \\
\text { X-ray diffraction (XRD), particle size } \\
\text { distribution }\end{array}$ & $\begin{array}{l}\text { Simple compressive strength, bulk density } \\
\text { water absorption }\end{array}$ & $\begin{array}{l}\text { Reduced mechanical strength and } \\
\text { increased water absorption due to the } \\
\text { plasticity of the waste }\end{array}$ \\
\hline Reis et al. (2020) & Particle size distribution & $\begin{array}{l}\text { Particle size distribution, simple } \\
\text { compressive strength and water } \\
\text { absorption }\end{array}$ & $\begin{array}{l}\text { Compressive strength and stable water } \\
\text { absorption with added waste }\end{array}$ \\
\hline $\begin{array}{l}\text { Siqueira and Holanda } \\
\text { (2015) }\end{array}$ & $\mathrm{X}$-ray diffraction (XRD) & $\begin{array}{l}\text { Particle size distribution, X-ray } \\
\text { diffraction (XRD), simple compressive } \\
\text { strength, water absorption and durability, } \\
\text { Scanning Electron Microscopy (SEM) }\end{array}$ & $\begin{array}{l}\text { Reduction in porosity, good durability, } \\
\text { strength and stable absorption (up to } 20 \% \\
\text { of waste) }\end{array}$ \\
\hline Siqueira et al. (2016) & Drying and screening & $\begin{array}{l}\text { Volumetric shrinkage, X-ray diffraction } \\
\text { (XRD), water absorption, bulk density, } \\
\text { compressive strength, and durability }\end{array}$ & $\begin{array}{l}\text { Low volumetric shrinkage, decreased } \\
\text { porosity and water absorption, increased } \\
\text { durability and reduced compressive } \\
\text { strength with } 30 \% \text { waste }\end{array}$ \\
\hline Ashour et al. (2015) & Drying & Thermal conductivity & $\begin{array}{l}\text { Decrease in density and thermal } \\
\text { conductivity }\end{array}$ \\
\hline $\begin{array}{l}\text { Subramaniaprasad } \\
\text { et al. (2014) }\end{array}$ & Unidentified & Water absorption & $\begin{array}{l}\text { Increase in water absorption with added } \\
\text { residue }\end{array}$ \\
\hline
\end{tabular}


Table 3 - Continuation.

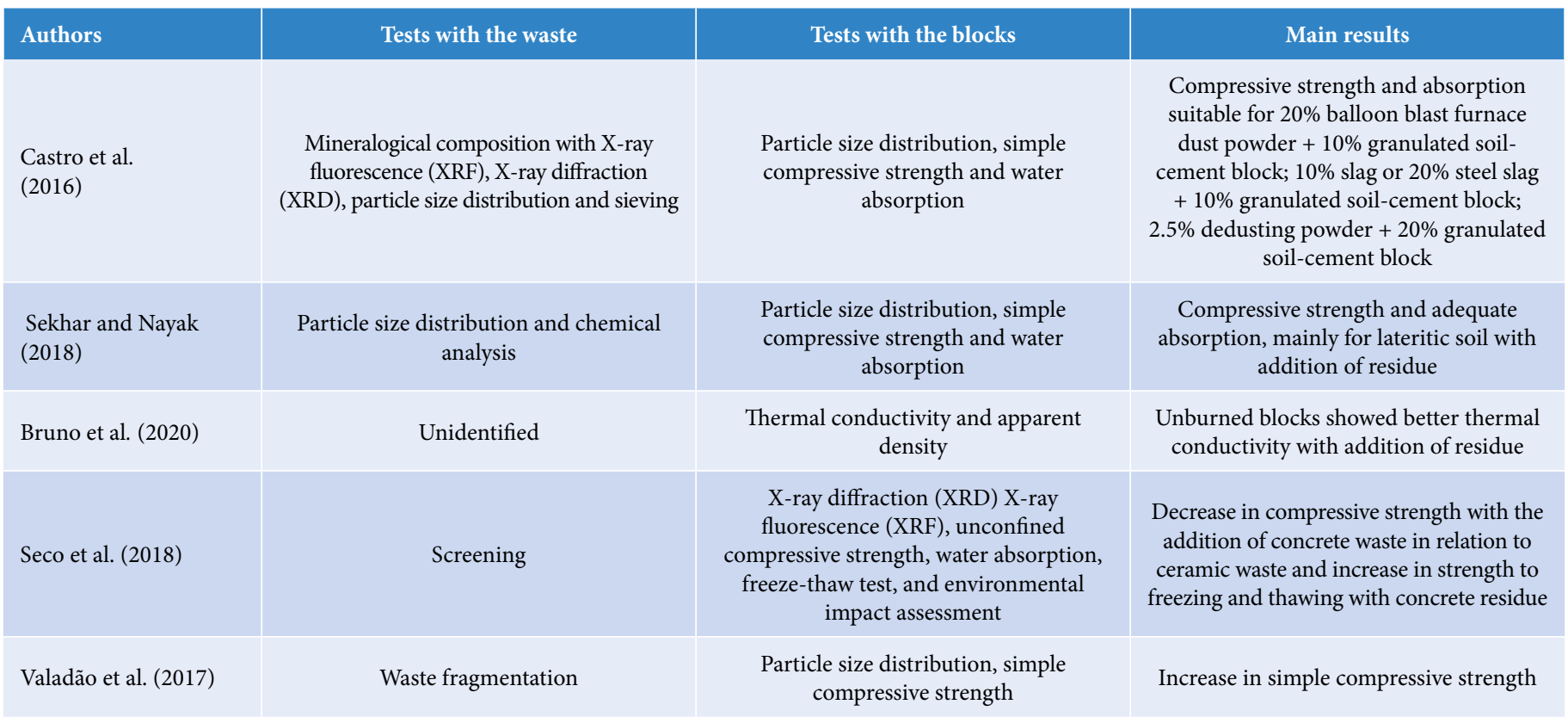

However, as for solubilization, the soil-cement brick with added grits presented constituents that are solubilized in concentrations higher than those allowed by NBR 10005 (ABNT, 2004b) in relation to the water potability pattern, realizing that this would impede the molding of soil-cement bricks.

Leonel et al. (2017) evaluated the incorporation of foundry sand into soil-cement bricks and found leaching values that did not exceed the limit established by NBR 10004 (ABNT, 2004a); therefore, the materials could be classified as non-hazardous. However, a solubilization test indicated that the phenol did not incorporate wastes; therefore, it is not an adequate component for the brick molding process. Cement and soil were classified as non-inert non-hazardous wastes, but in relation to cement, the parameters that exceeded the limits were chromium, phenol, sodium, and sulfate, and, for the soil, aluminum and iron.

\section{Life cycle analysis (lca) in civil construction: an alternative to evaluate soil-cement blocks with industrial solid waste}

Life Cycle Assessment (LCA) is an increasingly efficient and recognized tool, as it enables the assessment of the impacts of raw material extraction up to the final disposal of the products, providing knowledge about its different process phases (De Lassio et al., 2016). Several studies highlight LCA as an important tool for the civil construction sector in terms of sustainability in civil construction. (Galan-Marin et al., 2016; Marcelino-Sadaba et al., 2017; Peng and Wu, 2017; Joglekar et al., 2018; Lozano-Miralles et al., 2018; Mohajerani et al., 2018; Sandanayake et al., 2018; Seco et al., 2018; Yuan et al., 2018).

Yuan et al. (2018) compared permeable blocks and traditional concrete blocks and used LCA to analyze and compare the environmental and economic impacts, in addition to identifying the main processes and materials that make them beneficial for achieving a cleaner and more economical production. Seco et al. (2018) analyzed the incorporation of construction and demolition waste in non-sintered blocks and identified, through LCA, the environmental impact caused by these materials. Galan-Marin et al. (2016) conducted environmental impact studies in different construction systems, highlighting the masonry walls of sintered clay bricks, concrete block masonry, and masonry walls of soil blocks stabilized with natural fibers through LCA. Mohajerani et al. (2018) performed a comparative LCA to assess the environmental impacts of sintered blocks incorporating biosolids. Joglekar et al. (2018) evaluated different masonry alternatives in lowcost housing units, in order to define the material that represents the greatest sustainability.

Studies by Lozano-Miralles et al. (2018) evaluated the LCA of sintered blocks with organic waste and stated that using LCA can be a promising alternative approach regarding sustainability. Peng and $\mathrm{Wu}$ (2017) demonstrated, through modeling methodologies and ecological indicators, an LCA of carbon emissions from a modeled building and emphasized that this type of resource can be very useful in reducing efforts to estimate data, as it provides much-needed information and tools to perform this type of analysis. Thus, it alleviates part of the 
difficulty when executing the structuring of an LCA, since this study requires a vast database, and most of the time the obstacle is information acquisition.

According to Marcelino-Sadaba et al. (2017), the variability in the components of a product, the lack of data for each aspect of manufacturing and the processes involved create great challenges. As a result, through the incorporation of recycled waste and by-products, the quantification of data becomes more complex. For the authors, the incorporation of these materials creates problems in terms of data and means of conducting a robust and individualized analysis. Sandanayake et al. (2018) justify that a typical construction project involves several activities that cause particular environmental impacts and that, from this, a broader view of studies with a global perspective is necessary.

Through this approach, it is possible to verify the feasibility of applying LCA in new studies on the production of soil-cement blocks, as it allows a deeper analysis of the process and the material in question. In this sense, the quantification of data by using this methodology can enhance future studies, although Seco et al. (2018) emphasize that LCA also has the limitations of not fully considering the additional environmental benefits of replacing a non-renewable resource, such as natural soil, with recycled waste. Thus, it is still necessary to have broader and standardized details for future analysis of soil-cement blocks containing solid industrial waste.

\section{Final considerations}

Considering the general aspects of the discussion of literature in this study, the wastes that contributed to the improvement of soil-cement blocks properties were cellulose industry grains, rice husks, Brachiaria grass, steel by-products with soil blocks, granular cement, and blast furnace slag. The wastes that did not obtain satisfactory results were sludge from a water treatment plant, sugarcane bagasse, and vegetable loofah.

Through this article, it was possible to verify that the behavior of soil-cement blocks is influenced by several factors in their manufacture, mainly regarding the type and percentage of incorporated waste. Many wastes prove to be viable for use in this type of block in certain proportions, which is thus a sustainable alternative to their inadequate disposal in landfills and the environment. However, it is important to be concerned about the application of blocks with such wastes, requiring more environmental analyses linked to these types of studies so that the intention of these surveys is truly sustainable and does not enhance environmental impacts.

\section{Contribution of authors:}

Silva, T.R.: Conceptualization, Methodology, Formal analysis, Investigation, Data curation, Software, Writing — original draft. Cecchin, D.: Methodology, Validation, Resources, Supervision, Project administration. Azevedo, A.R.G.: Methodology, Validation, Resources, Supervision, Project administration. Alexandre, J.: Formal analysis, Software, Resources. Valadão, I.C.R.P.: Formal analysis, Visualization. Bernardido, N.A.: Formal analysis, Visualization. Do Carmo, D. F.: Methodology, Validation, Visualization. Ferraz, P. F. P.: Validation, Visualization.

\section{References}

Al-Fakih, A.; Mohammed, B.; Liew, M.S.; Nikbakht, E., 2019. Incorporation of waste materials in the manufacture of masonry bricks: an update review. Journal of Building Engineering, v. 21, 37-54. https://doi.org/10.1016/j. jobe.2018.09.023.

Al-Jabri, K.S.; Hago, A.W.; Sthapit, G., 2017. Properties of soil-cement blocks manufactured using produced water from oil fields: a preliminary investigation. International Journal of Geomate, v. 13, (35), 66-72. http:// dx.doi.org/10.21660/2017.35.6671.

Anjum, T.; Khan, H.I.; Shauket, I., 2017. Production of soil-cement bricks using sludge as a partial substitute. Earth Science Malaysia, v. 1, (2), 10-12. http://dx.doi.org/10.26480/esmy.02.2017.10.12.

Araújo, C.; Salvador, R.; Piekarski, C.; Sokulski, C.; Francisco, A.; Camargo, S., 2019. Circular economy practices on wood panels: a bibliographic analysis. Sustainability, v. 11, (4), 1057. https://doi.org/10.3390/su11041057

Arrigoni, A.; Grillet, A.-C.; Pelosato, R.; Dotelli, G.; Beckett, C.T.S.; Woloszyn, M.; Ciancio, D., 2017. Reduction of rammed earth's hygroscopic performance under stabilization: an experimental investigation. Building and Environment, v. 115, 358-367. https://doi.org/10.1016/j.buildenv.2017.01.034.
Ashour, T.; Korjenic, A.; Korjenic, S.; Wu, W., 2015. Thermal conductivity of unfired earth bricks reinforced by agricultural wastes with cement and gypsum. Energy and Buildings, v. 104, 139-146. https://doi.org/10.1016/j. enbuild.2015.07.016.

Associação Brasileira de Cimento Portland - ABCP. 2000. Fabricação de tijolos de solo-cimento com a utilização de prensas manuais. $3^{\mathrm{a}}$ ed. ABCP, São Paulo, $16 \mathrm{pp}$.

Associação Brasileira de Normas Técnicas - ABNT. 2004a. NBR 10004: Classificação de Resíduos Sólidos. ABNT, Rio de Janeiro, 71 pp.

Associação Brasileira de Normas Técnicas - ABNT. 2004b. NBR 10005: Procedimento para obtenção de extrato lixiviado de resíduos sólido. ABNT, Rio de Janeiro, $16 \mathrm{pp}$.

Associação Brasileira de Normas Técnicas - ABNT. 2012a. NBR 8491: Tijolo de solo-cimento - Requisitos. ABNT, Rio de Janeiro, 5 pp.

Associação Brasileira de Normas Técnicas - ABNT. 2012b. NBR 8492: Tijolo de solo-cimento - Análise dimensional, determinação da resistência à compressão e da absorção de água - Método de ensaio. ABNT, Rio de Janeiro, 4 pp. 
Azevedo, A.R.G.; Marvila, T.M.; Júnior Fernandes, W.; Alexandre, J.; Xavier, G.C.; Zanelato, E.B.; Cerqueira, N.A.; Pedroti, L.G.; Mendes, B.C., 2019. Assessing the potential of sludge generated by the pulp and paper industry in assembling locking blocks. Journal of Building Engineering, v. 23, 334-340. https://doi.org/10.1016/j.jobe.2019.02.012.

Balaguera, A.; Carvajal, G.I.; Albertí, J.; Fullana-I-Palmer, P., 2018. Life cycle assessment of road construction alternative materials: a literature review. Resources, Conservation and Recycling, v. 132, 37-48. https://doi. org/10.1016/j.resconrec.2018.01.003.

Balaji, N.C.; Mani, M.; Venkatarama Reddy, B.V., 2017. Thermal conductivity studies on cement-stabilised soil blocks. Proceedings of Institution of Civil Engineers: Construction Materials, v. 170, (1), 40-54. https://doi.org/10.1680/jcoma.15.00032.

Bardin, L., 1977. Análise de conteúdo. 70, Persona, Lisboa, 224 pp.

Barros, M.M.; Oliveira, M.F.L.; Ribeiro, R.C.C.; Bastos, D.C.; Oliveira, M.G., 2020. Ecological bricks from dimension stone waste and polyester resin. Construction and Building Materials, v. 232, 117252. https://doi.org/10.1016/j. conbuildmat.2019.117252.

Ben Mansour, M.; Ogam, E.; Jelidi, A.; Cherif, A.S.; Jabrallah, S.B., 2017. Influence of compaction pressure on the mechanical and acoustic properties of compacted earth blocks: An inverse multi-parameter acoustic problem. Applied Acoustics, v. 125, 128-135. https://doi.org/10.1016/j. apacoust.2017.04.017.

Bruna, G.C.; Vizioli, S.H.T., 2006. Social housing with soil-cement brick as a structuring element for the sustainable development of João Dourado (BA). Brazilian Journal of Environmental Sciences (Online), (4), 43-49.

Bruno, A.; Gallipoli, D.; Perlot, C.; Kallel, H., 2020. Thermal performance of fired and unfired earth bricks walls. Journal of Building Engineering, v. 28, 101017. https://doi.org/10.1016/j.jobe.2019.101017.

Buyle, M.; Braet, J.; Audenaert, A., 2013. Life cycle assessment in the construction sector: A review. Renewable and Sustainable Energy Reviews, v. 26, 379-388. https://doi.org/10.1016/j.rser.2013.05.001.

Campbell, J.W.; Pryce, W. 2003. Brick a world history. Thames \& Hudson, London, $320 \mathrm{pp}$.

Campos, A.; Nascimento Junior, J.B.; Brito, L.T., 2019. Structural behavior of soil-cement bricks using different sources of water and healing methods. Interações, v. 20, (1), 283-296. https://doi.org/10.20435/inter.v0i0.1565.

Cardoso, A.; Gallato, S.; Guadagnin, M., 2014. Estimated generation of construction waste and feasibility study for a sorting and recycling plant. Brazilian Journal of Environmental Sciences (Online), (31), 1-10.

Carrasco, E.V.M.; Silva, S.R.; Mantilla, J.N.R., 2014. Assessment of mechanical properties and the influence of the addition of sawdust in soil-cement bricks using the technique of ultrasonic anisotropic inspection. Journal of Materials in Civil Engineering, v. 26, (2), 219-225. https://doi.org/10.1061/(ASCE) MT.1943-5533.0000723.

Castro, A.L.; Pandolfelli, V.C., 2009. Review: concepts of particle dispersion and packing for special concretes production. Cerâmica, v. 55, (333), 18-32. https://doi.org/10.1590/S0366-69132009000100003.

Castro, M.A.M.; Costa, F.G.; Borba, S.C.; Fagury Neto, E.; Rabelo, A.A., 2016. Avaliação das propriedades físicas e mecânicas de blocos de solo-cimento formulados com coprodutos siderúrgicos. Revista Matéria, v. 21, (3), 666-676. https://doi.org/10.1590/S1517-707620160003.0064.

Cristina, P.; Salomão, P.E.A.; Cangussú, L.; Carvalho, P.H.V., 2018. Brick solo cement with vegetable fiber addition: an alternative in civil construction. Research, Society and Development, v. 7, (9), e779439. https://doi. org/10.17648/rsd-v7i9.439.
De Lassio, J.; França, J.; Santo, K.E.; Haddad, A., 2016. Case study: LCA methodology applied to materials management in a Brazilian residential construction site. Journal of Engineering, v. 2016, 8513293. https://doi. org/10.1155/2016/8513293.

Fernandes, F.M.; Lourenço, P.B.; Castro, F., 2010. Ancient clay bricks: manufacture and properties. In: Dan M.B., Přikryl R., Török Á. (Eds.), Materials, technologies and practice in historic heritage structures. Springer, Dordrecht, pp. 29-48.

Ferreira, D.; Luso, E.; Cruz, M., 2018. Blocos ecológicos de solo-cimento com incorporação de resíduos. Construction Pathology, Rehabilitation Technology and Heritage Management, v. 2018, 1368-1376.

Ferreira, R.; Gobo, J.; Cunha, A., 2008. Incorporação de casca de arroz e de braquiária e seus efeitos nas propriedades físicas e mecânicas de tijolos de solo-cimento. Engenharia Agrícola, v. 28, (1), 1-11. https://doi.org/10.1590/ S0100-69162008000100001

Ferreira, R.C.; Cunha, A.H.N., 2017. Quality evaluation of soil-cement-plant waste bricks by the combination of destructive and non-destructive tests. Revista Brasileira de Engenharia Agrícola e Ambiental, v. 21, (8), 543-549. https://doi.org/10.1590/1807-1929/agriambi.v21n8p543-549.

Galan-Marin, C.; Rivera-Gomez, C.; Garcia-Martinez, A., 2016. Use of naturalfiber bio-composites in construction versus traditional solutions: operational and embodied energy assessment. Materials, v. 9, (6), p. 465. https://doi. org/10.3390/ma9060465.

Huarachi, D.A.; Gonçalves, G.; Francisco, A.C.; Canteri, M.H.G.; Piekarski, C.M., 2020. Life cycle assessment of traditional and alternative bricks: a review. Environmental Impact Assessment Review, v. 80, 106335. https://doi. org/10.1016/j.eiar.2019.106335.

Joglekar, S.N.; Kharkar, R.A.; Mandavgane, S.A.; Kulkarni, B.D., 2018. Sustainability assessment of brick work for low-cost housing: A comparison between waste-based bricks and burnt clay bricks. Sustainable Cities and Society, v. 37, 396-406. https://doi.org/10.1016/j.scs.2017.11.025.

Jordan, R.A.; Costa, M.V.; Martins, E.A.S.; Rosa, M.A.; Petrauski, A., 2019. Manufacture of soil-cement bricks with the addition of sugarcane bagasse ash. Engenharia Agrícola, v. 39, (1), 26-31. https://doi.org/10.1590/1809-4430-Eng. Agric.v39n1p26-31/2019.

Kadir, A.A.; Mohajerani, A., 2011. Bricks: an excellent building material for recycling wastes - a review. IASTED International Conference on Environmental Management and Engineering, v. 2, 108-115.

Kadir, A.A.; Mohajerani, A., 2012. Properties improvement of fired clay bricks incorporating with cigarette butts. Advanced Materials Research, v. 535-537, 1723-1730. https://doi.org/10.4028/www.scientific.net/ AMR.535-537.1723.

Krishna, R.S.; Mishra, J.; Meher, S.; Das, S.K.; Mustakim, S.M.; Singh, S.K., 2020. Industrial solid waste management through sustainable green technology: Case study insights from steel and mining industry in Keonjhar, India. Materials Today: Proceedings, v. 33, (part 8), 5243-5249. https://doi. org/10.1016/j.matpr.2020.02.949.

Kurmus, H.; Mohajerani, A., 2020. Recycling of cigarette butts in fired clay bricks: a new laboratory investigation. Materials, v. 13, (3), 790. https://doi. org/10.3390/ma13030790.

Leonel, R.F.; Folgueras, M.V.; Dalla Valentina, L.V.O.; Prim, S.R.; Prates, G.A.; Caraschi, J.C., 2017. Characterization of soil-cement bricks with incorporation of used foundry sand. Cerâmica, v. 63, (367), 329-335. https:// doi.org/10.1590/0366-69132017633672131. 
Li Piani, T.; Weerheijm, J.; Peroni, M.; Koene, L.; Krabbenborg, D.; Solomos, G.; Sluys, L.J., 2020. Dynamic behaviour of adobe bricks in compression: The role of fibres and water content at various loading rates. Construction and Building Materials, v. 230, 117038. https://doi.org/10.1016/j. conbuildmat.2019.117038.

Lozano-Miralles, J.A.; Hermoso-Orzáez, M.J.; Martínez-García, C.; Rojas-Sola, J.I., 2018. Comparative study on the environmental impact of traditional clay bricks mixed with organic waste using life cycle analysis. Sustainability, v. 10, (8), 2917. https://doi.org/10.3390/su10082917.

Marcelino-Sadaba, S.; Kinuthia, J.; OTI, J.; Meneses, A.S., 2017. Challenges in life cycle assessment (LCA) of stabilized clay-based construction materials. Applied Clay Science, v. 144, 121-130. https://doi.org/10.1016/j.clay.2017.05.012.

McGregor, F.; Heath, A.; Fodde, E.; Shea, A., 2014. Conditions affecting the moisture buffering measurement performed on compressed earth blocks. Building and Environment, v. 75, 11-18. https://doi.org/10.1016/j. buildenv.2014.01.009.

Mohajerani, A.; Ukwatta, A.; Setunge, S., 2018. Fired-clay bricks incorporating biosolids: Comparative life-cycle assessment. Journal of Materials in Civil Engineering, v. 30, (7), 1-12. https://doi.org/10.1061/(ASCE)MT.19435533.0002308

Muñoz, P.; Morales, M.P.; Letelier, V.; Mendívil, M.A., 2016. Fired clay bricks made by adding wastes: Assessment of the impact on physical, mechanical and thermal properties. Construction and Building Materials, v. 125, 241-252. https://doi.org/10.1016/j.conbuildmat.2016.08.024.

Murmu, A.L.; Patel, A., 2018. Towards sustainable bricks production: an overview. Construction and Building Materials, v. 165, 112-125. https://doi. org/10.1016/j.conbuildmat.2018.01.038.

Nascimento, E.P., 2012. Trajetória da sustentabilidade: do ambiental ao social, do social ao econômico. Estudos Avançados, v. 26, (74), 51-64. https://doi. org/10.1590/S0103-40142012000100005.

Neves, C.; Faria, O.B., 2011. Técnicas de construção com terra. FEB-UNESP/ PROTERRA, Bauru, 79 p (Accessed November 19, 2020) at: http://www. redproterra.org

Oliveira, J.R.; Garcia do Amaral, A.; Schneider, R.M., 2014. Incorporação de resíduos sólidos de tornearias mecânicas na fabricação de tijolos solo-cimento. Nativa, v. 2, (1), 53-57. https://doi.org/10.31413/nativa.v2i1.1370.

Paschoalin Filho, J.A.; Storopoli, J.H.; Dias, A.J.G., 2016. Avaliação da resistência à compressão e da absorção de água de tijolos de solo cimento manufaturados com adição de resíduos de pet (politereftalato de etileno). Acta Scientiarum Technology, v. 38, (2), 163-171. https://doi.org/10.4025/actascitechnol.v28i2.28458.

Peng, C.; Wu, X., 2017. Retracted: case study of carbon emissions from a building's life cycle based on BIM and Ecotect. Advances in Materials Science and Engineering, v. 2017, 2193505. https://doi.org/10.1155/2017/2193505.

Pinheiro, M.L.; Alvarenga, R.C.S.S.; Ribeiro, B.C.; Silva Júnior, P.R.; Sarmet, P.S.; Fassoni, D., 2013. Experimental evaluation of pressed blocks of soilcement with grits addition. Ambiente Construído, v. 13, (2), 29-46. https://doi. org/10.1590/S1678-86212013000200004.

Raut, A.N.; Gomez, C.P., 2017. Development of thermally efficient fibre-based eco-friendly brick reusing locally available waste materials. Construction and Building Materials, v. 133, 275-284. https://doi.org/10.1016/j. conbuildmat.2016.12.055.

Reis, F.M.D.; Ribeiro, R.P.; Reis, M.J., 2020. Physical-mechanical properties of soil-cement bricks with the addition of the fine fraction from the quartzite mining tailings (State of Minas Gerais - Brazil). Bulletin of Engineering Geology and the Environment, v. 79, 3741-3750. https://doi.org/10.1007/s10064-020-01765-3.
Rempel, A.R.; Rempel, A., 2016. W. Intrinsic evaporative cooling by hygroscopic earth materials. Geosciences, v. 6, (3), 38. https://doi.org/10.3390/ geosciences6030038.

Rodrigues, L.P.; Holanda, J.N.F., 2015. Recycling of water treatment plant waste for production of soil-cement bricks. Procedia Materials Science, v. 8, 197-202. https://doi.org/10.1016/j.mspro.2015.04.064.

Rodseth, C.; Notten, P.; Von Blottnitz, H.A., 2020. A revised approach for estimating informally disposed domestic waste in rural versus urban South Africa and implications for waste management. South African Journal of Science, v. 116, (1-2), 1-6. https://doi.org/10.17159/sajs.2020/5635.

Romeiro, A.R., 2012. Desenvolvimento sustentável: uma perspectiva econômica ecológica. Estudos Avançados, v. 26, (74), 65-92. https://doi. org/10.1590/S0103-40142012000100006.

Saidi, M.; Cherif, A.S.; Zeghmati, B.; Sediki, E., 2018. Stabilization effects on the thermal conductivity and sorption behavior of earth bricks. Construction and Building Materials, v. 167, 566-577. https://doi.org/10.1016/j. conbuildmat.2018.02.063.

Sandanayake, M.; Zhang, G.; Setunge, S.A., 2018. Comparative method of air emission impact assessment for building construction activities. Environmental Impact Assessment Review, v. 68, 1-9. https://doi.org/10.1016/j. eiar.2017.09.003

Santos, C.F.R.; Alvarenga, R.C.S.S.; Ribeiro, B.C., 2013. Tijolos de solocimento-couro: caracterização física e mecânica de teores de misturas. Elecs, 1-13. http://dx.doi.org/10.12702/978-85-89478-40-3-a049.

Seco, A.; Omer, J.; Marcelino, S.; Espuelas, S.; Prieto, E., 2018. Sustainable unfired bricks manufacturing from construction and demolition wastes. Construction and Building Materials, v. 167, 154-165. https://doi. org/10.1016/j.conbuildmat.2018.02.026.

Segantini, A.A.S.; Wada, P.H., 2011. Estudo de dosagem de tijolos de solo-cimento com adição de resíduos de construção e demolição. Acta Scientiarum - Technology, v. 33, (2), 179-183. http://dx.doi.org/10.4025/ actascitechnol.v33i2.9377.

Sekhar, C.D.; Nayak, S., 2018. Utilization of granulated blast furnace slag and cement in the manufacture of compressed stabilized earth blocks. Construction and Building Materials, v. 166, 531-536. https://doi. org/10.1016/j.conbuildmat.2018.01.125.

Sena, R.J.; Laursen, A.; Silva, J., 2017. Avaliação mecânica de tijolo maciço solo-cimento contendo resíduo de pet. Veredas, v. 10, (1), 69-83.

Silva, W.M.; Ferreira, R.C.; Souza, L.O.; Silva, A.M., 2009. Effect of the incorporation of agro-industrial residues on the mechanical and thermophysical characteristics of soil-cement modular bricks. Brazilian Journal of Environmental Sciences (Online), (14), 9-14.

Silva, W.M.; Ferreira, R.C.; Souza, L.O.; Silva, A.M., 2010. Management of construction and demolition waste and its use as a base, sub-base and bituminous mixture in urban pavement in Goiânia - GO. Brazilian Journal of Environmental Sciences (Online), (15), 1-9.

Siqueira, F.B.; Amaral, M.C.; Bou-Issa, R.A.; Holanda, J.N.F., 2016. Influence of industrial solid waste addition on properties of soil-cement bricks. Cerâmica, v. 62, (363), 237-241. https://doi.org/10.1590/0366-69132016623631969.

Siqueira, F.B.; Holanda, J.N.F., 2015. Effect of incorporation of grits waste on the densification behavior of soil-cement bricks. Cerâmica, v. 61, (360), 414419. https://doi.org/10.1590/0366-69132015613601917.

Slipa Kasa, S.; Yao, L.; Perinaz, B.T.; Woerden, F.V. 2018. What a Waste 2.0 - A global snapshot of solid waste management to 2050. World Bank, Washington, D.C., $271 \mathrm{p}$. 
Smol, M.; Kulczycka, J.; Henclik, A.; Gorazda, K.; Wzorek, Z., 2015. The possible use of sewage sludge ash (SSA) in the construction industry as a way towards a circular economy. Journal of Cleaner Production, v. 95, 45-54. https://doi.org/10.1016/j.jclepro.2015.02.051.

Subramaniaprasad, C. K.; Abraham, B.M.; Nambiar, E.K.K., 2014. Sorption characteristics of stabilised soil blocks embedded with waste plastic fibres. Construction and Building Materials, v. 63, 25-32. https://doi.org/10.1016/j. conbuildmat.2014.03.042.

Subramaniaprasad, C.K.; Abraham, B.M.; Nambiar, E.K.K., 2015. Influence of embedded waste-plastic fibers on the improvement of the tensile strength of stabilized mud masonry blocks. Journal of Materials in Civil Engineering, v. 27, (7), 1-7. https://doi.org/10.1061/(ASCE)MT.1943-5533.0001165.

United Nations. 2020. A ONU e o meio ambiente. (Acessed November 2020) at: https://nacoesunidas.org/acao/meio-ambiente/.

Valadão, I.; Domingos, F.; Queiroz, I.; Silva, K.; Leal, L., 2017. Tijolo ecológico confeccionado com cédulas de dinheiro sem valor. Semioses, v. 11, (4). http:// dx.doi.org/10.15202/1981996X.2017v11n4p64.

Venkatarama Reddy, B.V.; Jagadish, K.S., 2003. Embodied energy of common and alternative building materials and technologies. Energy and Buildings, $\mathrm{v}$. 35, (2), 129-137. https://doi.org/10.1016/S0378-7788(01)00141-4.
Weber, E.; Campos, R.; Borga, T., 2017. Analysis of the efficiency of ecological brick solo-cement in civil construction. Ignis, v. 6, (2), 18-34.

Yuan, X.; Tang, Y.; Li, Y.; Wang, O.; Zuo, J.; Song, Z., 2018. Environmental and economic impacts assessment of concrete pavement brick and permeable brick production process - A case study in China. Journal of Cleaner Production, v. 171, 198-208. http://dx.doi.org/10.1016/j. jclepro.2017.10.037.

Zakham, N.; El Rhaffari, Y.; Ammari, A.; Cherraj, M.; Bouabid, H.; Gueraoui, K.; Samaouali, A.; Mzerd, A., 2018. Influence of cement content on the thermal properties of compressed earth blocks (CEB) in the dry state. MATEC, v. 149, 1-5. https://doi.org/10.1051/ matecconf/201814901059.

Zhang, L., 2013. Production of bricks from waste materials - A review. Construction and Building Materials, v. 47, 643-655. https://doi.org/10.1016/j. conbuildmat.2013.05.043.

Zhang, Z.; Wong, Y.C.; Arulrajah, A.; Horpibulsuk, S., 2018. A review of studies on bricks using alternative materials and approaches. Construction and Building Materials, v. 188, 1101-1118. https://doi.org/10.1016/j. conbuildmat.2018.08.152. 